\title{
Soviet Worship Cantatas and Oratorios \\ of the Late 1950s - Early 1980s \\ for Children's Chorus
}

\author{
Natalia V. Perepich* \\ Krasnoyarsk State Institute of Art \\ 22 Lenin Str., Krasnoyarsk, 660049, Russia
}

Received 24.09.2015, received in revised form 11.10.2015, accepted 19.11.2015

Cantatas and oratorios for the children's choir in the USSR at the time of the "thaw" and "developed socialism" are studied in the research paper. The large number of these compositions is the evidence of the certain tradition formation and is determined by the fact that the party leaders gave them great value in guided ideological education of the younger generation. The model of the world approved in the Soviet Union is represented in the compositions for the pioneers, the events of national history are highlighted, the themes of communism development, the succession of generations, patriotism and service to the native land are involved. Musical and poetic means of their implementation are subjected to the problems of affordable, spectacular and vivid representation, creating an appropriate emotional atmosphere. The complex of vivid and recognizable means and techniques, typical of the worship genre of music, such as solemn fanfare entrance, major mode, basis on the genre model of march, song-march, anthem and waltz, referring to the techniques of musical vividness and instrumental theatricality are used in the music.

Keywords: soviet music, worship compositions, cantata, oratorio, children's choir, the Pioneers.

DOI: 10.17516/1997-1370-2016-9-1-169-183.

Research area: art history.

Compositions of different genres and forms that meet a number of criteria are referred to the field of worship music. The most important of them are: the function of glorification, praise and approval of the state and its leaders; the heroes, who distinguished merits to the homeland, as well as the events that were landmark for it; presence of the poetic text that sends the message of the leaders' greatness, the episodes of history and, as a whole, the specific state to the audience; confinement to the events and dates landmark for the state; appropriate performance conditions: the situation of official celebrations, a large number of listeners; attracting major orchestras and bands in accordance with the event grandness, vast spaces or areas; special stylistics (literary and musical) as a system of means that in this case are intended to create jubilant and triumphant mood, inspire the listeners the sense of unity, pride, etc.; compositional and dramaturgical patterns: presence of the final section, which serves as the culmination of worship-glorifying.

(C) Siberian Federal University. All rights reserved

* Corresponding author E-mail address: kgamit@list.ru 
In Soviet times, worship music with the support of state authorities was involved in the primary tasks solution (representational, educational, propaganda, etc.). In the 1920s early 1950s, a large number of compositions of different genres, mainly for mixed instrumentation, which sometimes involved the choir of pioneers, was written. The interest of composers to worship cantatas and oratorios for the children audience is observed since the mid-1950s. The suite by S. Sosnin, cantatas and oratorios by A. Pakhmutova, A. Petrov, A. Fliarkovsky, O. Khromushin, L. Sidelnikov, V. Vitlin, Ya. Dubravin and G. Gladkov that appeared in the late 1950s - early 1980s are among them. They were available to a wide audience: sounded in concerts and broadcast on the radio and television to all the parts of the country. A significant feature of worship genres of music was evidently also recognized in the education of the new generation of Soviet people. The role of such compositions in shaping the world view of the Little Octobrists and Pioneers is apparent because their poetic lyrics and music was a kind of "ABC" of the younger citizens. Traditional ideological principles, as well as basic images, techniques and means of expression developed in the official Soviet music found their implementation in them.

When reconstructing the Soviet model of the world in the lyrics of oratorios and cantatas for children's choir, the major events of the Soviet history: the Revolution, the activities and the death of Lenin, the development of the Soviet Union and the Great Patriotic War are featured. It is interesting that the Tsarist Russia is not mentioned in them, and Soviet historical time is interpreted through the prism of mythological "genealogy" of the citizens from the "grandfathers" (revolutionaries) to the "fathers" (the heroes of the Great Patriotic War) and "children and grandchildren" (Little Octobrists and Pioneers of the time of the "thaw" and "developed socialism"). According to this, the idea of generic continuity of the Pioneer qualities from their ancestors, the members of heroic events is asserted in the lyrics. However, there is no equivalence of tenses in the cantatas: narration about the past which mobilizes to perform actions in the "adult" future is prevalent in them.

The top of the social hierarchy is the image of the leader, whose name is often used in the lyrics of pioneer cantatas and oratorios. A lot of objects and landmarks, named after him: the Red Square, the Mausoleum, the Lenin Library, the plant named after Lenin, Luzhniki, the city of Leningrad ${ }^{1}$ are mentioned in the lyrics. The symbol of tireless work and concern for the Soviet people are the places of his stay: the office where the girl who ran up "to the beloved Ilyich" felt asleep, (Cantata by V. Vitlin "Burn, Pioneer's Bonfire!”), lake Razliv, where he "was sitting by the campfire dreaming" and "had been working the whole night" (in the lyrics by V. Shoshin from the cantata by V.O. Khromushin "Lenin is With Us").

It is noteworthy that in the compositions for children's choir creation of ideas about the communist world is based upon the idea of preservation the idealized image of the leader, endowed with metaphysical properties in the hearts of the "fervent Leninists": "I saw Lenin's image everywhere - at work, in smiles and in the hearts of the Muscovites!", "Lenin is with us, lives in our hearts", "Lenin is in the hearts of adults and children, Lenin lives while our hearts are beating" (lyrics by N. Dobronravov, V. Verkhovsky and V. Shoshin).

In the texts of cantatas and oratorios of the 1950 s - early 1980 s, the Pioneers are characterized as the rising generation responsible for the extension of the "golden age" of communism: "Even though we are now younger than all the deputies, we are the Soviet government, too!" (in the lyrics by N. Dobronravov), "And now a 
Pioneer is a Communist, a citizen of the $21^{\text {st }}$ century" (in the lyrics by V. Kriuchkov), "All that Lenin bequeathed us to do, we are, the young, will complete" (the lyrics by V. Verkhovsky). First of all, multiplicity and unity of the members of the Pioneer organization is emphasized: "There are millions of us, young and daring", "Nowadays there are millions of Pioneers in the world", "The first, the second, $<\ldots>$ the tenth, the thousandth, the millionth! Here are our columns" (in the lyrics by S. Grebennikov, N. Dobronravov and V. Verkhovsky).

In the cantata by A. Pakhmutova "Lenin is in Our Hearts" a Soviet pioneer (the second narrator recites on his behalf) is introduced to a foreign friend using the poetic trope of periphrasis: "I am a young Leninist, I am the brother of the Komsomol", what demonstrates the highest degree of ideological and collective unity. In the cantata by Ya. Dubravin set on the lyrics by V. Suslov, the Pioneer is an exceptional example of the man of the future ("He looked into the great expanse of the sky and presented the Universe the earthy song"), whose dreams are "above the stars in the sky".

The concept of distinct social hierarchy is formed in the pioneers' consciousness from the early years. Organizations, which number of members is expanding as a Soviet citizen grows older (the little Octobrists have the "star" and the group (class), the Pioneers have the squad, the detachment and the team) are listed in the lyrics. According to the established order the Pioneers had the honorary status, they were entrusted with socially significant responsibility: buglers, drummers, commanders and the members of Timur movement. In some texts the evidence of the completeness and the organized life of the young generation is mythological interpretation of the Pioneer organization as an autonomous state: "There is a country - the Pioneers' country, but you can not find it on the map" (in the cantata by A. Flyarkovsky "The Pioneers' Country" set on the lyrics by V. Tatarinov). The objects of "national importance" in the lyrics are camp "Artek" as a symbol of friendly unity of pioneers all over the world, and the Pioneer Palace, from which in A. Pakhmutova's cantata "Lenin is in Our Hearts" guests begin their acquaintance with Moscow.

The lyrical tone of narration is used to describe the life of Soviet children, cheerful and joyful attitude is embodied in each piece of lyrics. The lines about strong friendship, clear song and first love are penetrated with romantic spirit. The images of the sun, which "rises higher and higher" (V. Tatarinov), the scarlet dawn, spring and nature (the sky, rain, thunderstorm, wood, meadow, stream, flowers and apple trees) dominate in the lyrics. Most often, they are represented through personification, and the pioneer naturally fits into this world as a good friend: "Our Pioneer salute to the blue rivers and sheer cliffs!" (Ya. Serpin), "The sun, you are on the way with us - we admit you to the Pioneers" (N. Dobronravov). Quite often, the images of nature reveal the meanings associated with the Soviet symbols. Thus, mentioning of the thunderstorm, which took place at the dawn, is conventionally associated with rebellion, planting white apple trees is a parallel to the peaceful country development, and the phrase "May rain" refers to the workers' "May day meetings" and festive demonstrations of the workers.

The side of life of a Soviet schoolchild, subordinated to the "statutory" rules is accented in the lyrics. As a member of the pioneer ceremony, he/she was getting ready to serve the native country from the first years. The Pioneers' attributes, including horn, which regulates the daily routine, the drum ("the Pioneer veteran"), that regulates the future Communists' consistency of steps, and the red neck tie, "the younger 
brother of the great banners, that accomplished the revolution", function as the primary symbols. This mark of distinction, given only to the initiated ones, in lyrics appears as a symbol of courage and perseverance, which was threatened by the enemy during the revolution and the Great Patriotic War (it was "ripped off”, "burned" and "shot at").

It is indicative that in the poetic episodes telling about the pioneer life, the vocabulary used in military affairs (unit, training, banner, columns, parade, formation, oath, order and campaign) prevails. Such words and phrases are found in the verses devoted to the Revolution, the Great Patriotic War and the theme of the world peace: feat, fighting, soldier, fighters, hero, enemy, squads, "to beat the White army", "ready to serve the native land", "to march steps", "guerrilla skills", "military song" and "the thunder of songs". The Pioneers' activity is of "heroic" nature: the procedure of initiation into the "squad of Leninists" with a parade and oath, trips to the places of battle actions, gatherings at the campfire and specific games ("Zarnitsa game"). The peers who died young serve as the example for the young generation: a revolutionary Pavlik Andreev, a fighter against the kulaks Pavlik Morozov, a partisan Zoya Kosmodemyanskaya, guerrillas Volodia Dubinin and Vitia Korobkov, a shipboy Sasha Kovalev, a medical assistant Gulya Koroleva and the hero of the novel by N. Ostrovsky "How the Steel Was Tempered" Pavka Korchagin.

"Childhood years is the period of search. Reading room, bonfire, stadiums and classroom ..."3: a number of motifs, which were essential for the formation of a Soviet citizen were reflected in the poetics of the pioneer cantatas and oratorios of the late 1950s - early 1980s. Their "foundations" are the provisions from the "Moral Code of the Builder of Communism" and "the Laws of the Pioneers": "the Pioneer is the best in studies, work and sport", "the Pioneer is an honest and loyal friend ...", "the Pioneer is a friend of other pioneers and the children of the working people of all countries".

- The motif of learning, based on Lenin's legacy, dominates in lyrics about the school and the choice of the future path of the pioneer: "Grandchildren of Korolev, Kurchatov and Tsiolkovsky... The stars of further discoveries, we can see from the desks", "make friends with a good book, there is no better friend", "the dawn lit the tip of the pen", "our youth is always aimed to storm the unprecedented scientific heights", "look - inquisitive people enter Lenin Library". In the text by N. Dobronravov the importance of extensive knowledge of a Soviet schoolchild under conditions of scientific and technological progress is emphasized, for which the neologism terms (PhysicalTechnical Institute, pulsar, mu-meson, antimatter, thermonuclear, quantum, synchrophasotron and electronic computing machine) are used.

- The motive of value-creating labour is reflected in many compositions: "the factory sirens, the factory sings", "Lenin worked all night long”, "carry nursery plants - faster", "it is necessary for every heart to know this great joy of labor", "the country of steelmakers, the country of farmers, all of us are your apprentices", "the due time will come, the country will entrust the machine to my hands", "working hands make the history of our native land". As well as in the narrations about Lenin, who "worked" and "dreamed", the images of work and dreams are intertwined: "we have to find our dream and honour our native land!", "everything he [the 
Leader] dreams about, everything will come true in the native land", "the cherished dream of the young Leninists is always young".

- The motif of sport competitions is traced in the lyrics about the benefits of physical education. These are the texts about Lenin Stadium in the cantata by

A. Pakhmutova ("seconds call us to compete", "we dedicate our records to our Leninist party", "only brave is called an athlete") and the football tournament among amateur teams "Leather Ball" in the cantata by Yu. Chichkov ("because every boy is a fan and a knight of the brave football game").

- The motif of friendship is one of the key ones, characterizing the Pioneers and the Soviet system: "let song and laughter sound together", "our peoples are befriended by October forever", "friendship of people in the world will contribute to peace", "those who have become friends, will strengthen their friendship forever".

- The motif of good and help to people is the core of "humane relationships", officially declared in the "Code" of 1961, fills the lyrics about Soviet life and the social role of a pioneer - "Timurite": "you can not make a single step without human participation, as well as you can not become a man without love and labor", "we send people joy to the forgotten addresses", "smiles pay gold for the magical work"

In the cantatas and oratorios for children's choir the lines from such significant Soviet samples of officialdom as the Internationale ("We will build our new world. He who was nothing will become everything!") and the Anthem of the Pioneers (an allusion "And the blue nights soared, soared then, soared by bonfires" refers to it) are quoted. In the lyrics of the analyzed opuses a lot of Soviet slogans (appeals and proclamations) are concentrated, the abundance of which is intensified by repetition: "Pioneer means the first, it means always ahead", "Everybody listen!", “Always ready!", "Go forward!", "Always ready to fight for Lenin's legacy!", "Be ready to serve the native country!", "War to war!", "No single step back!", "Peace to the blue planet!", "On with the work!", "Study, study and study", "We swear to live as Lenin lived!”. In addition, there are counting rhymes ("Oh, counting rhyme, counting rhyme, the river on the right, the beam on the left..."), phrases in the spirit of cadence ("Detachment means together/ We need to go through the years", "who beats who, let us bet", "come on, guys, broaden your steps") and proverbs: "the red banner is our hope and belief", "live in friendship - live richer life", "books are the friends of man", "pioneers detachment is a good school", "who had become friends in Artek - made friends forever".

In the poetic texts of these compositions stylistic figures that provide expressiveness of intonation (rhetorical appeal, rhetorical exclamation and rhetorical question), similarity and, quite often, repetition of the text structures (anaphora, epiphora, syntactic parallelism and mirror permutation of abba stanzas) play an important role. Variety of the poetic tropes, promoting more vivid and particular representation of the images of the Soviet model of the world to the children's audience is used in the lyrics.

Personification, which clauses could possibly appear under the influence of folk poetry, is most commonly used: "factory shops are breathing", "birch trees try on the red tie of dawn", "Red Square washes with the dawn and smiles", "look, Moscow is meeting us with a smile", "talented hero city is striving to become better and more beautiful", "seconds call us to compete", "and the 
tired planet believes the young", "and everybody heard the factory sirens wept wistfully". In the examples of simile the combination other tropes characteristics (metaphor, hyperbole and personification) are found, in some cases they reach high intensification "a red soldier is stronger than the robber's steel", "he stands as a soldier on the parade!", "Moscow Ilyich plant is seething, restless as the sea", "and the glow of the great lights of October burns on our ties as the dawn". It gives the lyrics originality, special expressiveness and strong emotional tone.

The use of metaphor as a mean of poetic language enrichment leads to lyrical and idealized interpretation of the Soviet life: "The Earth is our common home", "Lenin! He is the lighting lighthouse far off", "Lenin is in the hearts of adults and children", "the young dream sounds endlessly in this song", "the wings are spreading and we want to sing", "the dawn of generations lit above us", "the neck tie flies as a red winged bird", "the dawns of sunrise are our buglers". Metonymy (trope, where direct name of an object is replaced by another one, preserving its important characteristic) represents the images of the October revolt and brings pathetic sounding to the lyrics of the pioneer cantatas: "and the blue night then soared with bonfires", "the growls of songs in the sky", "opening doors to October", "the immortal melody of struggle bubbles in the copper pipe's throat". Through the use of antithesis the past and the present, the time of war and peace are traditionally compared: "someone first cautiously stepped forward out of the darkness to the light", "both triumphant shouts of victory, and the silence of common graves", "good winds and a fiery hour, fairy tales and fiction".

Constant epithet - a fixed phrase used in the poems of different authors is widely represented in the texts of the cantatas and oratorios for children's choir: the Red Star, the eternal star, the Kremlin star, the scarlet banner, the flag of October victory, the Pioneers' salute, the red neck tie, the combat song, Lenin's bonfire, Lenin's legacy, Lenin's actions, the great Lenin's path, the Soviet country and native homeland. Some of them in their functions and emotional and expressive style are close to the phrases from the folk texts; in others the symbols of the state are approved.

Worship cantatas and oratorios for children's choir of the late 1950s - early 1980s are major compositions for soloists, chorus and orchestra (piano), organized, as a rule, into multipart compositions that include from four to ten sections. Their musical language is accessible for the children's audience. To implement the key images and communist ideas stated in the texts, composers operate the tools and techniques conventional for the worship genre opuses. Development of the poetic text in music is accompanied by the complex of intonations, rhythmic formulas and tone qualities with established and understandable for the listener semantics. As a result of intensive use by different authors, a lot of musical and expressive means become a kind of a code for the audience's perception. Thus, the typical elements of the worship compositions' language are fixed in the pioneer's memory associating with the idea of glorification of the Soviet state and its heroes, the rise of patriotic feelings and pride for the country, awareness of the special role of worship genre in the Soviet culture.

Many compositions and their parts begin with the full entrance with dominating signal thematism, major mode and loud dynamics, dense orchestra (piano) texture, as, for example, in the cantata "Detachment Songs" by A. Pakhmutova (Fig. 1).

In a number of cases, the entrance is a long fanfare, melodic ${ }^{6}$ and chordal (as in I, V and VI sections of the cantata by $\mathrm{O}$. Khromushin 

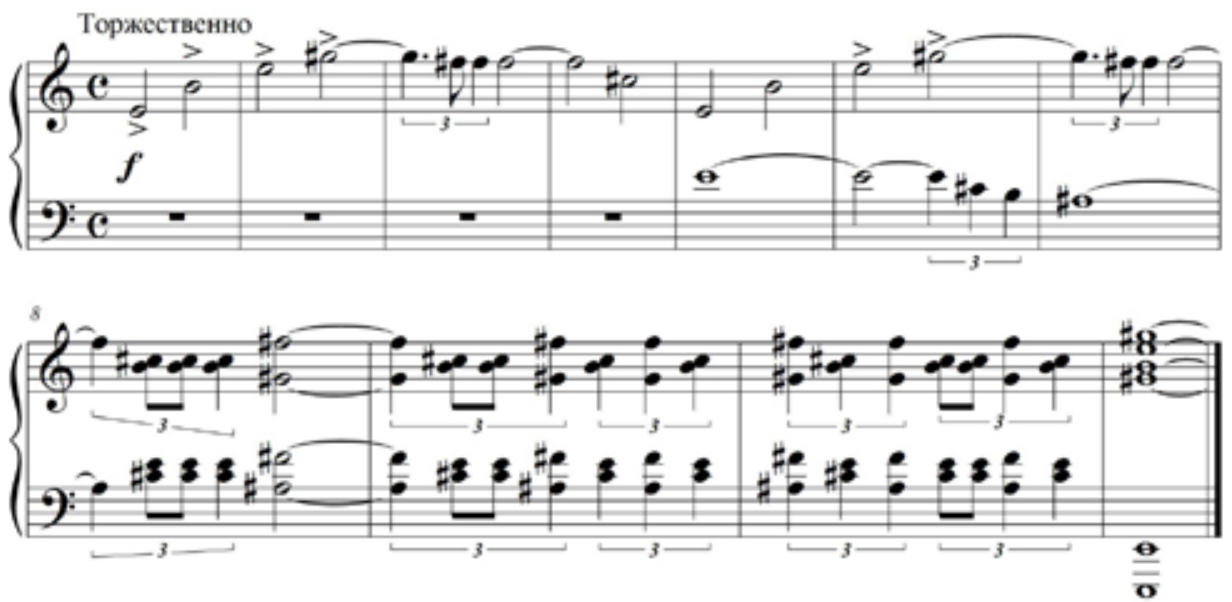

Fig. 1

"Lenin is with us" and in I and X sections of the cantata "Pioneer Means the First" by Ya. Dubravin and the cantata "Lenin Is in Our Heart" by A. Pakhmutova). Vividness and invocatory nature of its intonations contribute to activation of the audience attention and report the solemnity and heroic mode of the described events.

The authors refer to the genre models of march and song-march, leading in the Soviet mass processions and military parades. Dominating in cantatas and oratorios for children's choir, they convey the listener courage and elevation of spirit, represent the idea of the team unity and organization. In the middle section of the cantatas allegro and triple meter are common, which indicates the priority of dance start. In the part "Celebration in Artek" from the cantata by V. Vitlin within perfection the combination of dance rhythms takes place, revealing, according to the author's plan, the idea of fellowship of the pioneers in different countries. In its middle section there is a basis on the genre of waltz, popular at that time among the Soviet mass audience. Quite often waltz mediums are concentrated in the music of parts, while the accompaniment formula of waltz is rare ("Pathfinder's Bonfire" by Ya.
Dubravin and "Who Have Made Friends in Artek" by V. Vitlin, chorus of "The Ballad of the Shipboy Sasha Kovalev" by Yu. Chichkov). An exceptional example of the composer's interest to duple meter dance is the third section of the cantata "Detachment Songs" by A. Pakhmutova "The Tournament of Erudite", where genre features of polka dominate.

In the vocal melodics of the opuses under consideration quartal moves, dotted rhythm and fanfare momentum, typical of marching music are complemented with the romance intonations of lyrical sixth and small seconds, as well as conjunct movement, the leading notes motives and moves to the fifth, characteristic of Russian songs. Hymn-like beginning is manifested in the ascending direction of the melodic line, large scale and rhythm, leisurely pace of a number of finals and culminating episodes. The melodies of compositions for the pioneers are expressive and written in the tessitura easy for children's voices. Repetition of motifs, phrases and larger constructions plays a major role in their continuity, resulting in couplet and reprise forms formation. As a rule, introduction or the main theme of the composition is given to the soloist or performed by choir in unison, and 
there is polyphony in chorus, from two up to four voices.

In worship cantatas and oratorios for the Pioneers different techniques, determined by the influence of musical descriptiveness, can by observed. For example, in "The Evening", the III section of the oratorio "Happy Sun Above Us" by A. Flyarkovsky the possibilities of a capella ${ }^{7}$ choir are demonstrated. In harmonious four-voice texture the melody with the text ("coolness is flowing from the river...") is given to the first part, and the rest implement the function of harmonic support, intoning with the mouth closed. The lower voices development involves gradual rhythmic individualization, appearance of the new details, certain words and poetic phrases, introducing the elements of tone-painting, applying the techniques of sound (staccato and legato) and, as a result, the texture polyphonises.

In theaccompaniment of the section "Bonfire" (O. Khromushin) the harmonic figurations of sixteenth values dominate, evoking associations with the tongs of fire with its graphics, and at the end of III section of the cantata by B. Vitlin "Burn, Pioneer Bonfire!" fluttering of the pioneer banners in the wind is described by the means the piano texture. In the part "Hide and Seek" from the suite by S. Sosnin the call "The last will lead!" is followed by the cascade of downward melodic figurations to the short chords in the piano part, depicting running of the hiding children. In the II section of the oratorio by A. Flyarkovsky "Happy Sun Above Us" ("About Pavlik Andreev") the words of "The Internationale", which, according to the plot, the young revolutionary sang, are interrupted by the three short chords on ffff and flap of the palm in the lower register of piano that represent gunfire and death of the young hero. In the "Ballad on the Shipboy Sasha Kovalev" short tremolo of snare drum and repeated brass chords at the culmination imitate the bursts of machine gun fire and fire of the guns, and small second motives of the strings and woodwinds conditionally recreate the cries of sea gulls.

Presence of the developed reader's party in cantatas "To Ilyich" by L. Sidelnikov, "Pioneer Means the First" by Ya. Dubravin, "Lenin is in Our Heart" and "Detachment Songs" by A. Pakhmutova and oratorio "Happy Sun Above Us" by A. Flyarkovsky evidence of theater techniques effect. The composers' striving to enhance the spectacularity and game effect resulted in their varied use, including choral texture. In "The Tournament of Erudite" from the cantata "Detachment Songs" conversational parts are included: this part begins with the question of the soloist "What's that cries? What's that noise?", which is followed "in every way" by the choir. At the end of the first section of the choral part after the words "This question even great Archimedes can't answer" set on the music, voice insertion "He definitely knows!" is made. In the chorus questions, voiced by singing either the soprano or the alto, are addressed to the young erudite from all the sides: "How does the pulsar pulsate? When was mu-meson discovered? What is the power of antimatter? And who was Rutherford?".

In VII section of the cantata by V. Vitlin "In the Name of Lenin" ("Celebration in Artek") the choir is divided into two groups that sing phrases and theme motifs in turn what is associated with the voices of delegations from different countries, participating in the international pioneer celebration. In I and IV sections of the cantata "Burn, Pioneer Bonfire" by V. Vitlin in two parts of choir words and phrases of the lyrics are repeated as an "echo": "Now we will hear the voices of friends - we will hear; Ilyich - Ilyich; the fire is burning - the fire is burning". Other variants of the use of this technique: a combination of solo and polyphonic party that voices their lyrics with the mouth closed, or singing the vowel "A" ${ }^{8}$, the support of the leading party by singing a vowel in the choir ("Bonfire" and 
"Leningrad" in the cantata by O. Khromushin, "Wild Dog Dingo" in the cantata "Detachment Songs" by A. Pakhmutova) or completion of the choral chorus with it ("Pathfinder's Bonfire" in the cantata "Pioneer Means the First" by Ya. Dubravin and "Lenin Library" in the cantata "Lenin is in Our Heart" by A. Pakhmutova). Let us note special timbral sound vividness of vocal children's voices. Its introduction is associated, as a rule, with the images of Lenin's places, the fallen heroes, the Pioneer's bonfire, the first love, and contributes to their idealization and lirization.

The influence of theatricality can be also traced in the execution of vocal parties of the compositions. In the cantata by A. Petrov "Peace to the Blue Planet" the technique of choral rhythmic declamation is used to proclaim the slogans ("Peace! Peace! Peace to the blue planet!" P. 3). The same as in I section of the cantata by O. Khromushin "Lenin is With Us" (in the first stanza "Lenin! The bronze you look forward immortal!"). In II section of the cantatas by Ya. Dubravin and V. Vitlin ("In the Name of Lenin") dominate the melodies similar to declamation, what is reflected in their rhythmic freedom and basis on the range of speech intonations.

In instrumental accompaniment staging techniques distribution effect a permanent role of the main attributes of the Pioneer organization the drum and the bugle as the solo voices. The party of snare drum is represented in opuses both with orchestral and piano accompaniment ${ }^{9}$ : in the cantatas "To Ilyich" by L. Sidelnikov ("Marching" and "With Lenin in Heart"), "Pioneer Means the First" by Ya. Dubravin ("There Goes a Drummer"), "The Country of the Pioneers" by A. Flyarkovsky ("Comrade Drum"), "In the Name of Lenin" by V. Vitlin ("What Was Artek Like in the Beginning", "The Mystery of the Old Bugle" and "Marching"), "With Sunny Routes" by Yu. Chichkov ("The Ballad of the Shipboy Sasha
Kovalev"), oratorio "Happy Sun Above Us" by A. Flyarkovsky ("The First Detachments"). Its clear elastic rhythm that fills the daily life of the Pioneers is introduced in the sections about the struggle, acts of heroism and marching. The same is observed in relation to another leitmotif of the Country of Pioneers - signal bugle: it soloes and duplicates the chorus melody in "The Song of the Bugler" from the cantata by Ya. Dubravin.

Inherent to the theater arts idea of vivid representation of emotions, which represents a specific environment or situation and simulates the response of the audience, with a high degree of conditionality is manifested in pioneers' cantatas and oratorios of the late 1950s - early 1980s in the emphasis on major-mode modality. Major tones prevail when recreating the Soviet reality, worshipping Lenin and Revolution: C dur, F dur, D dur, B dur, A dur, Es dur, As dur, $\mathrm{H}$ dur, and occasionally Des dur. In the minor keys the parts telling about the battles of the past are represented: a moll ("Soldier's Grave" in the suite by S. Sosnin "We are the Grandchildren of the Revolution" and "The Bugler" in "Detachment Songs" by A. Pakhmutova), c moll ("The Songs of the Korchagins" from the cantata by O. Khromushin "Lenin is With Us" and "The Mystery of the Old Bugle" from the cantata by V. Vitlin "In the Name of Lenin"), d moll ("The Pathfinder's Bonfire" from the cantata by Ya. Dubravin "Pioneer Means the First"), b moll (part "Those Who Are Not with Us Any More" from the section "You, Children from Artek Are with Us Forever ..." in the cantata by V. Vitlin). In the oratorio by A. Flyarkovsky "Happy Sun Above Us" fis moll ("About Pavlik Andreev" and "The Heroes Are Not Forgotten"), es moll («The Oath of Allegiance" about Lenin's death) and f moll ("Understanding the Past") are presented. In general, it corresponds with the traditions established in the classical romantic music, where the aforementioned major keys are used to implement children, pastoral, idyllic 
images and solemn beginning and the minor ones intensity heroic and drama, dreary, distressful and mourning effect.

In the music contexture of the compositions there are intonation and rhythmic, as well as texture and harmonic modes that appear in the specific parts of forms and in the phrases of the poetic text and have the fixed means of expression. The stability of their figurative and semantic load and repeated return in the established context, vaguely reminds the principle of leitmotif characteristics in musical-theater genres. In addition, the stability of means and their repetition allow observing the commonness of their functions with musicalrhetorical figures.

Thus, in the cantatas "Peace to the Blue Planet" by A. Petrov (entrance and the choir chorus) and "Lenin is in Our Hearts" by A. Pakhmutova (in IV section in the orchestra with the words "Count Off!") there discloses an ascending conjunct motif, represented in a sequence of the intervals of sixths, fifths and thirds, which in Western music is known in as "golden ratio". The technique of "fanfare" with its invocatory quart intonation, dotted rhythm, iambic initial formula and loud dynamics, common in accompaniment, penetrates in the party of choir. This demonstrates the secondariness of instrumental genesis and primariness of connection with the poetic word, inherent to the musical-rhetorical figures. Introduction of solemn and invocatory signal from the official and military and sports repertoire brings relevant nuances in the text interpretation, accompanied by it. For example, the third section of the cantata by A. Pakhmutova about the factory named after Lenin "The Factory Sirens" begins with "fanfare-appeal" without instrumental accompaniment: the motif of ascending quart that is imitated in the party of soprano and then alto (Fig. 2).

As an onomatopoeic element, at the same time it contributes to the formation of solemn and heroic representations about the factory, which concerns the work of the laborers, the legendary arrival of Lenin that finished with the assassination attempt, and the dream of the young Leninists to work on the shopfloor.

IV section of the cantata by V. Vitlin "Burn, Pioneer Bonfire!" also starts with the choral fanfare. Two phrases of the text with ideological orientation ("everything that Lenin willed us to do" and "we, the young, will finish") are delimited by a brief instrumental ritornello (Fig. 3).

In a number of cantatas the last phrases of sections and parts that contain the images and ideas significant for the Soviet state are represented with the enlargement of rhythm, measure and time dilation, the length of the final tonic chord, increasing the dynamics and the number of texture voices. In this case, it is possible to talk about going beyond the length of the plot and bringing the idea of worshipping to the fore. Such constructions that have the status of musical and rhetorical figures of glorification in the Soviet worship opuses, mark the zone of cadence and reveal some aspects of particular relevance to children and youth audiences in the pioneers' cantatas and oratorios.

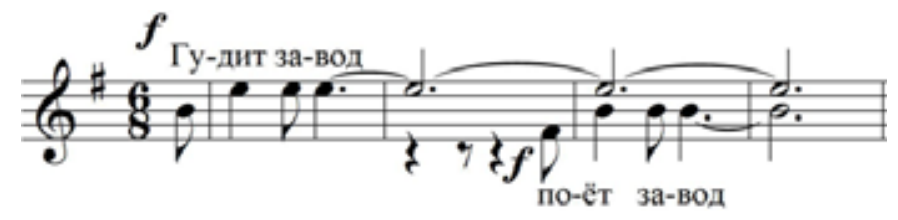

Fig. 2 


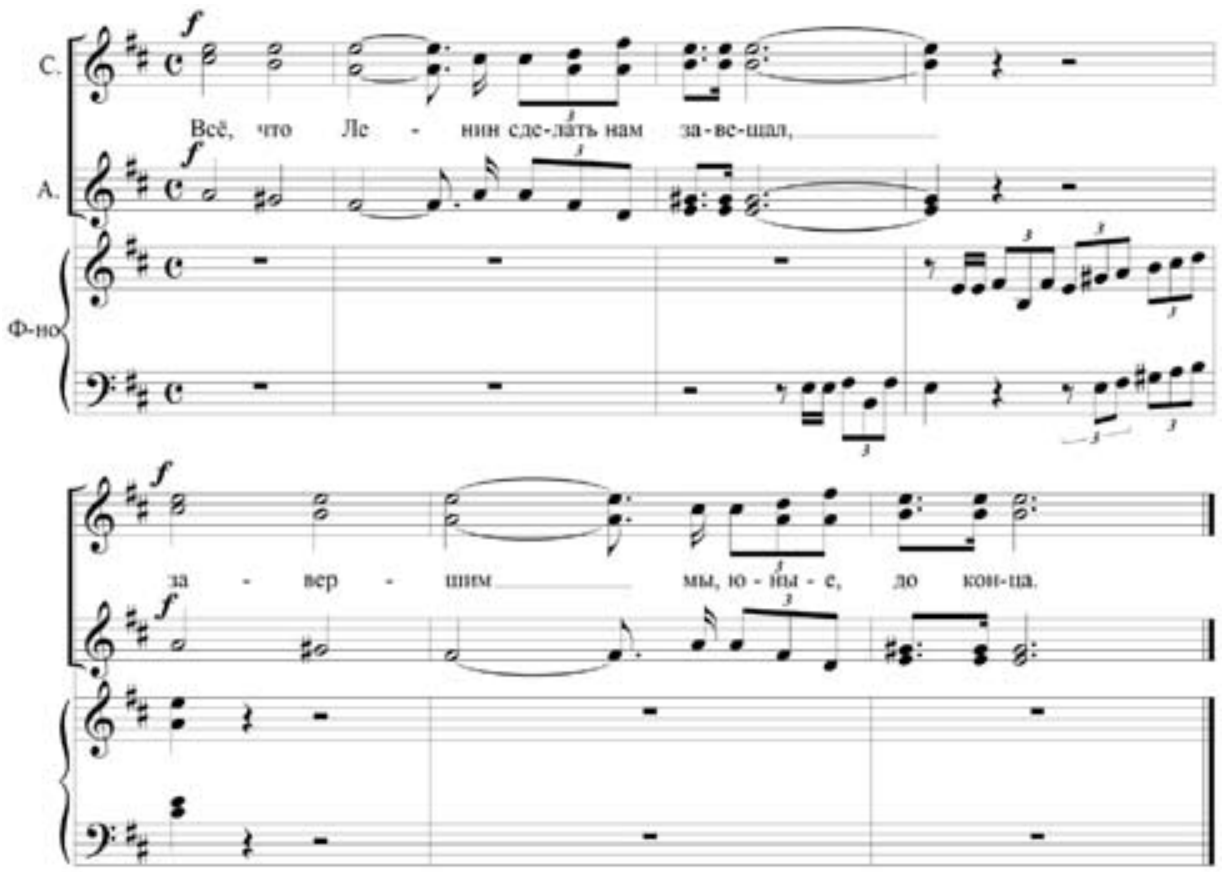

Fig. 3

First of all, it concerns the idea of glorification of the Soviet state. In the final of the cantata by A. Flyarkovsky the country of the Pioneers is glorified and its name is made a figure of glorification and in the last measures of the cantata by A. Petrov "Peace to the Blue Planet" the phrase "blossom the earth, our common home!" is represented through the aforementioned means.

The idea of honoring military glory and values of the deeds of fathers and grandfathers is manifested in IV section of the cantata by O. Khromushin "Lenin Is With Us" ("Leningrad"). In this case there are signs of the figure of glorification at the end of the phrase "we will proudly keep the honor of Leningrad as the holy thing of the native country!" (Fig. 4).

At the end of III section of the cantata by V. Vitlin "Burn, Pioneer Bonfire!" the important for the young Leninists idea of the strong pioneers friendship is manifested with its help (Fig. 5).

Thus, the cantatas and oratorios for children's choir of the times of the "thaw" and "developed socialism" indeed belong to the genre of worship music and are invoked to play a significant role in the Soviet citizens' education. They contain the key images and ideas of the communist world view. The lyrics of the compositions tells about the role of the first Leader and his legacy, raise issues about the structure of the social hierarchy, the qualities of the model communist, succession of generations and the junior's duty to the seniors. They illustrate the events of national history, the deeds of fathers and grandfathers, service to the native country and patriotism.

These ideas are manifested to the Pioneers' audience through the accessible musical and poetic means and techniques. In poetics we would like to emphasize extended use of rhetorical exclamations, rhetorical address and rhetorical question that give the lyrics intonation variety, as well as the trope of "constant epithet", which examples are actively replicated in the texts. There are cases of citation of the fragments of the Soviet anthems and high density of slogans in the 


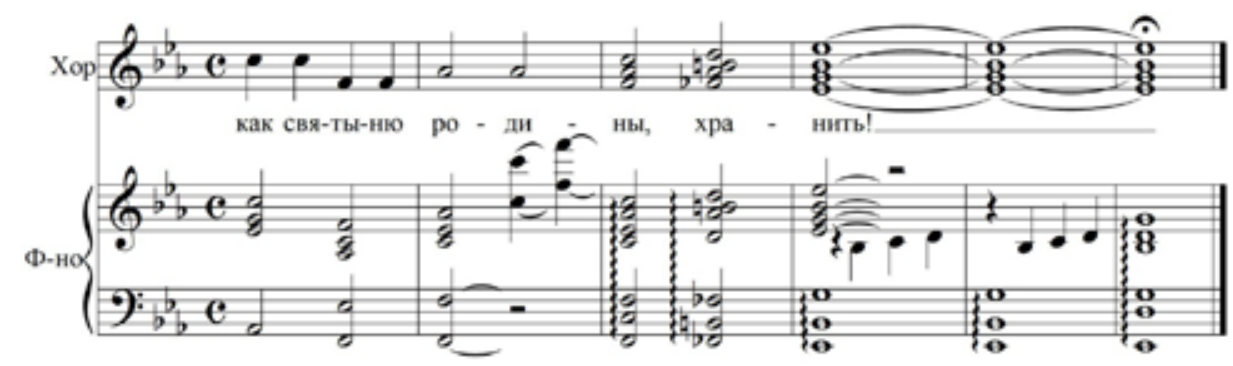

Fig. 4
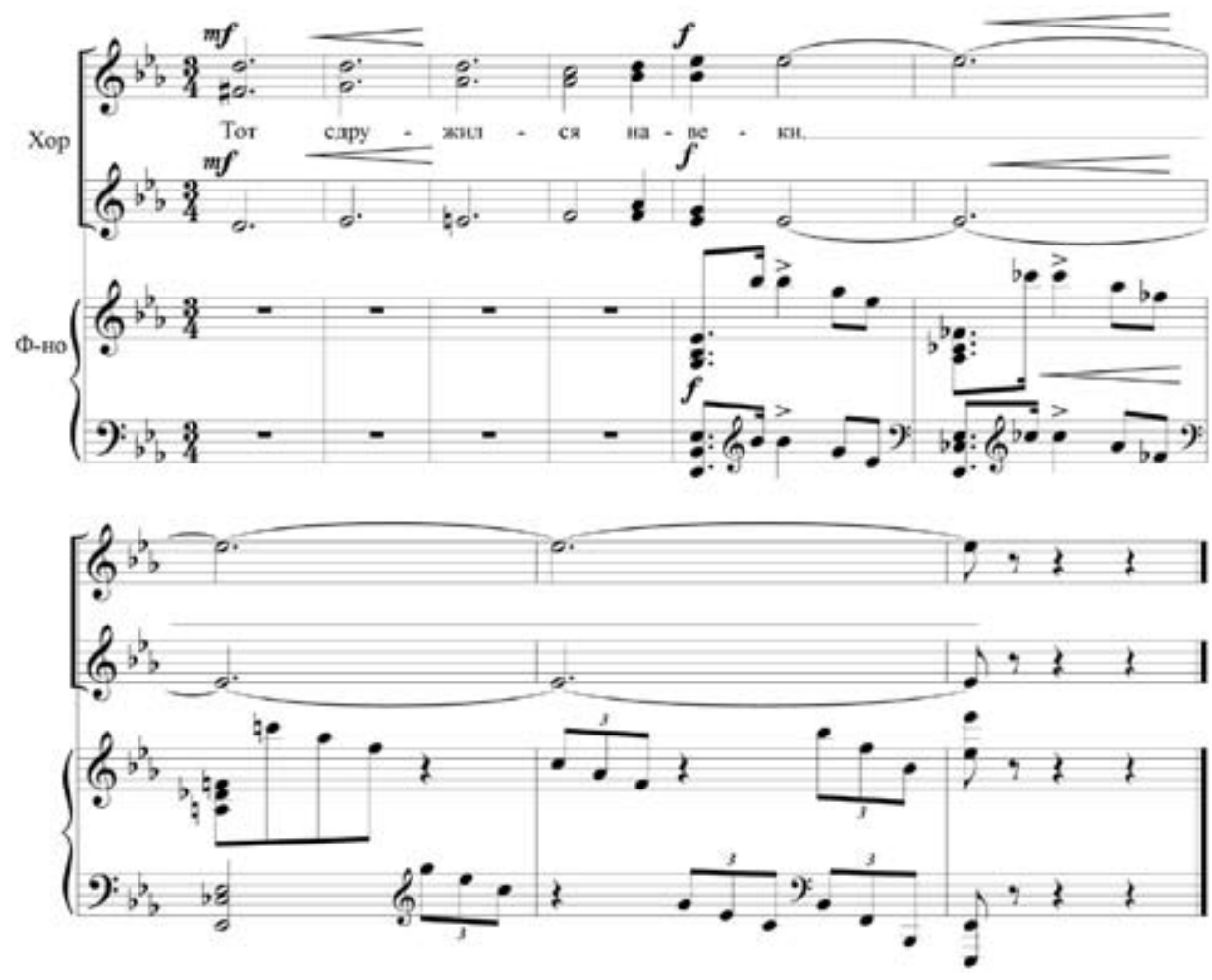

Fig. 5

lyrics. In the music of compositions the complex of the means of expression where the basic elements of musical vocabulary of the worship genre are concentrated plays an important role: fanfare overture, the antithesis of major and minor, aimed at manifestation of the good present and difficult past, basis upon the genre models of march, song-march, anthem and waltz. From the musical and rhetorical figures "fanfare" and the figure of glorification as a carrier of the idea of glorification and the sign of finishing the composition or its section are represented. They are also distinguished by the penetration of the techniques of musical figurativeness, specifying the poetic text and theatricalization (presence of the party of the reader, conversational parts, choral rhythmic declamation, soloing tones of the snare drum and bugle in accompaniment) and introducing spectacular and ludic basis into the compositions. 
Worship cantatas and oratorios for the children's choir of the late 1950s - early 1980s are preparing the young listener to perceive the "adult" officious music. At the same time, the Soviet model of the world is represented in them in the adaptive way to emphasize the primary moments (image of the party remains unrevealed, pre-revolutionary times are not shown). The ideas and stories that resonate with the theme of childhood (studying, playing, camping, dreaming and friendship) come to the forefront. This also affects the level of musical and poetic means: personification that prevails in the lyrics "animates" the phenomena of nature, the state objects, abstract concepts and neologisms are specified in the form of game, counting rhymes and cadences are used and the music of one of the sections is written in the familiar from the early age genre of polka.

With the Soviet era departure the theme of the Pioneers cantatas and oratorios lost relevance and their execution stopped. Today some sections of them, such as lyrical parts, devoid of ideological context are possible to hear. The largest part of the compositions remained nondemanded and the tradition of creating worship music for children that emerged in the last thirty years of the Soviet Union extinct. Meanwhile, these days patriotic education becomes significant again and it is obvious that music for children could contribute to its problems solution.

1 Starting from 1924 the Pioneer and Komsomol organizations were named after Lenin, an epithet “Lenin's Party" was used in the lyrics of the cantatas by A. Pakhmutova.

2 The given phrases from the texts, addressed to the pioneers of the late $1950 \mathrm{~s}$ - early 1980s, play the role of behavioral guidelines directed by ideological orientations: intolerance of the "White", service to the native land, the development of physical and communicative skills useful for a Communist.

3 From the cantata "The Detachment Songs" by A. Pakhmutova set on the lyrics by N. Dobronravov.

4 Where "conscientious labor for the good of society", "humane attitude and mutual respect between people: a man is a man's friend, comrade and brother", "friendship and brotherhood of all peoples of the USSR" are proclaimed.

5 Lines from the lyrics from the texts by Ya. Serpin, V. Suslov, N. Dobronravov, V. Shoshin, L. Barbas, V. Verkhovsky, V. Kruchkov and K. Ibriaev were taken as examples.

6 Entrance to the oratorio "Happy Sun above Us" by A. Flyarkovsky and its III secton "The First Detachments", to VI section "Zarnitsa" Game Gathers Troops" of the cantata by Ya. Dubravin "Pioneer Means the First", V ("Marching") and VIII ("Epilogue") sections of the cantata by V. Vitlin "In the Name of Lenin", I and IV sections of cantata by V. Vitlin "Burn, Pioneer Bonfire!"

7 Without instrumental accompaniment in worship compositions for children's audience there are also phrases that highlight important communist ideas: "golden sparkle became a flame" in the middle of the section "Bonfire" by O. Khromushin, "everything that Lenin bequeathed us to do, we, the young, will complete" in the beginning of IV section of the cantata "Burn, Pioneer Bonfire!" by V. Vitlin, etc.

8 In II section ("Bonfire") of the cantata "Lenin is With Us" by O. Khromushin and in the part "About Pavlik Andreev" from the oratorio "Happy Sun Above Us" by A. Flyarkovsky, IV section ("Ballade on the Shipboy Sasha Kovalev") of the cantata by Yu. Chichkov "With Sunny Routes" the singing of the soloist is followed by the introduction of choir without words (sound "A").

$9 \quad$ In the cantata by L. Sidelnokov the possibility of its substitution with piano is specified.

\section{References}

Vail' P., Genis A. 60-e: mir sovetskogo cheloveka [1960s: the World of the Soviet People]. Moscow, Corpus, 2013. $432 \mathrm{p}$.

Velikanova O.V. (1994) Obraz Lenina v massovom soznanii [The Image of Lenin in Mass Consciousness] // Otechestvennaia istoria (2), Pp. 177-185.

Vorob'ev I.S. Kantatno-oratorial 'nyi zhanr v sovetskoi muzyke 1930-1950kh godov: k probleme sotsrealisticheskogo "bol'shogo stilia" [The genre of Cantata and Oratorio in the Soviet Music of 1930s-1950s: About the Problem of Socialist "Big Style"]. Avtoreferat na soiskanie uchenoi stepeni doktora iskusstvovedeniia. Rostov-na-Donu, 2013. 46 p. 
Zenchenko O.V. (2010) Figura-simvol v istorii kul tury [Symbol-Figure in the History of Culture] // Voprosy kul'turologii (3), Pp. 28-33.

Zolotnitskii D.I. Zori teatral nogo oktiabria [The Dawns of the Theatre October]. Leningrad, Iskusstvo, 1976. $391 \mathrm{p}$.

Kabalevskii D.B. Dorogie moi druz’ia [My Dear Friends]. Moscow, Molodaia gvardiia, 1979. $187 \mathrm{p}$.

Lenzon V.M. Muzyka sovetskikh massovykh revoliutsionnykh prazdnikov [Music of Soviet Mass Revolutionary Celebrations]. Moscow, Muzyka, 1987. 78 p.

Meteleva S.S. (2013) Transformatsiia tsennostei: ot sovetskogo cheloveka k cheloveku obshchestva potrebleniia [The Transformation of Values: from the Soviet People to the People of Consumer Society] // Voprosy kul'turologii (1), Pp. 42-47.

Naiko N.M. Muzykal 'no-ritoricheskie figury "obnovlennoi Rossii” v vokal 'no-simfonicheskikh proizvedeniiakh D. Shostakovicha [Musical-Rhetorical Figures of the "Renewed Russia" in VocalSymphonic Compositions by D. Shostakovich] // Poznavshii tainu zvuka: stat' i o muzyke I muzykantakh. Krasnoiarsk, 2012, Pp. 131-150.

Perepich N.V. Otechestvennye slavil nye sochineniia 1950 - 1970kh godov: $k$ voprosu o znachenii printsipa teatralizatsii [Soviet Worship Compositions of 1950s - 1970s: About the Importance of Theatrical Principle] // Aktual nye problemy sovremennogo compozitorskogo tvorchestva. Materialy Vserossiiskoi nauchnoi konferentsii. Krasnoiarsk, 2014, Pp. 138-143.

Perepich N.V. Otechestvennaia slavil naia muzyka: etapy istorii [The Soviet Worship Music: the Stages of History] // Iskusstvo glazami molodykh: materialy VI Mezhdunarodnoi nauchnoi konferentsii studentov, aspirantov i molodykh uchenykh. Krasnoiarsk, 2014, pp. 26-29.

Ul K. (2011) Pokolenie mezhdu "geroicheskim proshlym" i "svetlym budushchim": rol "molodezhi vo vremia ottepeli [The Generation Between the "Heroic History" and the "Bright Future": the Role of the Youth in the Period of "Thaw"] // Antropologicheskii forum (15), Pp. 279-326.

Khokhlovkina A.A. Sovetskaia oratoriia i cantata [Soviet Oratorio and Cantata]. Moscow, Muzgiz, 1955. $118 \mathrm{p}$. 


\title{
Советские славильные кантаты
}

\section{и оратории конца 1950-х - начала 1980-х \\ для детского хора}

\section{Н.В. Перепич}

Красноярский государственный институт искусств Россия, 660049, Красноярск, Ленина, 22

\begin{abstract}
В статье анализируются славильные кантаты и оратории для детского хора в СССР времён «оттепели» и «развитого сочиализма». Многочисленность этих сочинений служст свидетельством формирования определённой традици и обусловлена тем, что партийное руководство придавало им большое значение в деле направленного идеологического воспитания подрастающего поколения. В произведениях для пионеров репрезентируется утверждаемая в Советском Союзе модель мира и освещаются события отечественной истории, затрагиваются темы становления коммуниста, преемственности поколений, патриотизма и служения Отчизне. Музыкально-поэтические средства их воплощения подчинены задачам доступного и зрелищного, красочного преподнесения, создания соответствующей эмоциональной атмосферы. В музыке используется комплекс ярких и узнаваемых средств и приёмов, характерных для опусов славильной жанровой сферы: торжественное фанфарное вступление, мажорный лад, опора на жанровые модели марша, песни-марша, гимна и вальса, обращение к приёмам музыкальной изобразительности и театрализации.
\end{abstract}

Ключевые слова: советская музыка, славильные сочинения, кантата, оратория, детский хор, пионеры.

Научная спеииальность: 17.00.02 - искусствоведение. 